Article

\title{
The Function of A Set-Aside Railway Bridge in Connecting Urban Habitats for Animals: A Case Study
}

\author{
Brigitte Braschler *(D), Claudine Dolt and Bruno Baur \\ Section of Conservation Biology, Department of Environmental Sciences, University of Basel, St. \\ Johanns-Vorstadt 10, CH-4056 Basel, Switzerland \\ * Correspondence: brigitte.braschler@unibas.ch
}

Received: 7 January 2020; Accepted: 2 February 2020; Published: 7 February 2020

check for updates

\begin{abstract}
As elements of green infrastructure, railway embankments are important corridors in urban environments connecting otherwise isolated habitat fragments. They are interrupted when railways cross major roads. It is not known whether dispersing animals use railway bridges to cross roads. We examined the function of a set-aside iron-steel railway bridge crossing a $12 \mathrm{~m}$ wide road with high traffic density in Basel (Switzerland) for dispersing animals. We installed drift fences with traps on a single-track, $32 \mathrm{~m}$ long and $6 \mathrm{~m}$ wide railway bridge with a simple gravel bed, and collected animals daily for 9 months. We captured more than 1200 animals crossing the bridge: small mammals, reptiles and amphibians as well as numerous invertebrates including snails, woodlice, spiders, harvestmen, millipedes, carabids, rove beetles and ants. For some animals it is likely that the gravel bed, at least temporarily, serves as a habitat. Many animals, however, were apparently dispersing, using the bridge to cross the busy road. We found season- and daytime-dependent differences in the frequency the bridge was used. Our findings indicate an important function of a set-aside railway bridges for connecting urban habitats. As most animal dispersal was recorded during the night, railway bridges with no (or little) traffic during the night may also contribute to animal dispersal. As important elements of green infrastructure, set-aside railway bridges should be considered in future urban planning.
\end{abstract}

Keywords: biodiversity; corridors; dispersal; greenways; green infrastructure; habitat connectivity; habitat fragmentation; invertebrates; urbanization; urban planning

\section{Introduction}

Urbanization is increasing worldwide with more and more people moving to expanding cities [1]. Within these cities the provision of open spaces is limited and unevenly distributed, enhancing the need to provide green infrastructure [2-4]. To connect these isolated patches linear structures that function as corridors between them are important $[2,5,6]$. Such urban greenways benefit residents by providing various regulating and cultural ecosystem services (e.g., experience of nature and improved health and wellness) and support biodiversity [6-9]. Most cities are growing rapidly and undergo densification processes, thus isolating remaining open spaces. There is an urgent need for further development of new urban green infrastructure $[10,11]$. In many cities, historic legacies such as military fortifications and former industrial land provide opportunities for establishing new greenways. Examples include the city wall circular greenway in Nanjing [12], the Ring Boulevard in Vienna [8,13] and the Green Belt Berlin established on the grounds of the former Berlin Wall [6]. Another opportunity for establishing new greenways is disused railway lines including their embankments or changes of the management of these structures. In urban areas, line-side land has a key function in connecting green areas [5] and a 
high conservation value has been assigned to a considerable proportion of railway embankments [14]. For example, over 1000 ha of line-side land in London have been identified as Sites of Importance for Nature Conservation (SINCs; [15]).

In this study, we focus on the connectivity aspect for supporting biodiversity. The fragmentation of natural habitats by transport infrastructure (highways and other roads with high traffic density, railways) has received a great deal of attention [16-18]. Various means to mitigate negative effects of habitat fragmentation have been suggested and the great importance of green bridges and other forms of wildlife passages have been documented repeatedly [19-21]. However, roads and railways do not only fragment habitats; their verges and embankments can also provide valuable semi-natural habitats [22,23] and serve as dispersal corridors [5,17]. In particular, line-side railway land (mainly grassland, but also scrub, woodland and ruderal vegetation) is of considerable importance [18]. Trackside vegetation prevents erosion, promotes pollinators (wild bees), provides habitat and functions as dispersal corridor for numerous plant and animal species and enhances quality of life to a city's residents $[23,24]$. However, it should be noted that corridors may also have negative aspects such as dispersal of invasive species, pathogens and diseases [25].

The gravel bed of a railway line itself may serve as a habitat for specialized invertebrate species. This aspect has so far received little attention. In contrast to line-side railway land and embankments, which are interrupted by bridges, stations or overpasses, the gravel bed continues through these structures. Thus, while the dispersal function of trackside vegetation might be interrupted when railway tracks cross rivers or roads on bridges with no or very little vegetation (e.g., on iron-steel constructions with simple gravel beds), the dispersal function may be less affected for species associated with the gravel bed. To our knowledge it is not known whether existing (extensively used or disused) railway bridges contribute to habitat connectivity by serving as a link between habitats.

Here we present a field study in which animals (vertebrates and invertebrates) crossing a 32 m-long railway bridge were monitored over a period of 9 months using drift fencing with pitfall traps. Not all animals captured on the bridge might have been caught while dispersing. For some invertebrates the gravel bed of a little-used railway track may also serve as habitat and in this way connect similar habitats on either side of the bridge.

Abiotic conditions (pronounced variation in temperature, lack of humidity) in the gravel bed of a railway bridge may act as a filter for dispersing animals. Depending on daily and seasonal activity patterns we expect that some taxonomic groups are less affected by particular conditions. In order to examine these aspects we emptied the traps twice per day separating day- and night-active animals.

Certain morphological or behavioral traits may determine whether the bridge can serve as a connecting habitat or a dispersal corridor for a species. In particular, body size may be connected to dispersal ability through the fit to the scale of interstitial spaces in the gravel bed or because of its relationship with the dispersal pace on the surface. By contrast, the bridge may not serve as a connecting habitat for arboreal species because of a lack of higher vegetation.

In particular, we tested the following hypotheses: (1) a set-aside railway bridge functions as a corridor for small animals providing landscape connectivity across the road. (2) Different taxonomical groups differ in frequency of bridge use. (3) Capture rates on the bridge are higher during the night than during the day, because many species can thus avoid exposure to predation and extreme microclimatic conditions, or are mainly nocturnal. (4) For different taxonomic groups capture rates differ among the seasons. (5) High temperatures and rainfall affect capture rates on the bridge. (6) Taxa with particular combinations of traits are more likely to use the bridge.

\section{Materials and Methods}

\subsection{Set-Aside Railway Bridge}

The bridge examined is located on the northeast edge of the railway station Badischer Bahnhof in Basel (Switzerland). The single-track, $32 \mathrm{~m}$ long and $6 \mathrm{~m}$ wide railway bridge is an iron-steel 
construction with a simple gravel bed of $30 \mathrm{~cm}$ depth (Figure 1a). The bridge crosses a major road (traffic density of 8000 vehicles per day) at an angle of $45^{\circ}$ and at a height of $5.5 \mathrm{~m}$ over a distance of 16 $\mathrm{m}$ (Figure 1a). At the southern bridgehead there is a $40 \times 100 \mathrm{~m}$ grassland adjacent to the wide gravel field of the railway station with 19 tracks. North of the bridge a second track joins at a distance of $60 \mathrm{~m}$ and after further $60 \mathrm{~m}$ both tracks cross the river Wiese on a $45 \mathrm{~m}$ long iron-steel bridge to the $200 \mathrm{~m}$ wide and $2 \mathrm{~km}$ long gravel covered marshaling yard of the Deutsche Bahn AG, a railway company.

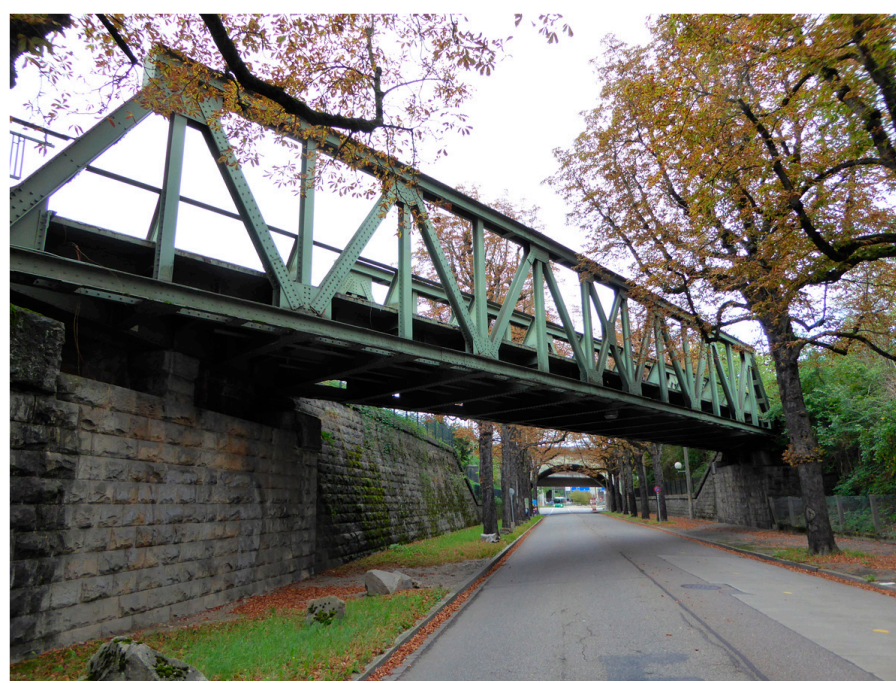

(a)



(b)

Figure 1. (a) Railway bridge as seen from the street. During the study period in 1996 the bridge was closed to traffic. (b) Drift fences and pitfall traps on the bridge. Fine-grained marl was added to seal any gaps beneath the fences. Some vegetation developed on the gravel bed of the bridge because the track was set aside for a period of 1 year.

\subsection{Trapping Animals}

In February 1996 we installed $40 \mathrm{~cm}$-high plastic drift fences from either bridgehead, which led the moving animals from both sides into two separate life traps (40 cm wide, $30 \mathrm{~cm}$ long and $50 \mathrm{~cm}$ deep) situated in the middle of the bridge (Figure 1b). This assignment allowed a separation of animals crossing the bridge from north to south from those moving from south to north. The lower edge of the plastic fences was buried in a layer of marl to prevent small animals from slipping under the fence. To separate invertebrates and their potential predators (small mammals, amphibians, reptiles) in the traps, we installed a horizontal net (mesh size $8 \mathrm{~mm}$ ) $5 \mathrm{~cm}$ above the bottom of each trap.

Trapping was conducted between 9 March and 30 November 1996. We checked the traps for captured animals twice daily early in the morning at dawn and in the evening at dusk from 1 March to 31 October. From 1 to 30 November, the traps were emptied every day early in the morning. Vertebrates captured were determined on the spot or photographed, tagged and released immediately on the opposite side of the bridge. Invertebrate animals (arthropods and gastropods) were preserved in 70\% alcohol for later species identification by experts (see Acknowledgments and Supplementary Table S3).

As a result of the set-aside of the bridge, a cover of vegetation developed on the gravel bed in the course of the study.

\subsection{Temperature in the Gravel Bed}

In order to characterize the temperature conditions of the gravel bed, four data loggers (Tiny Talk, Gemini Data Logger, Chichester, West Sussex) were buried in the gravel bed at a depth of $5 \mathrm{~cm}$ (two at every bridgehead and two at either end of the bridge between the rails). Temperature was recorded every $30 \mathrm{~min}$ between 14 March and 29 November 1996. Temperature readings from the two 
loggers with the same position from either end of the bridge were averaged for analysis to represent the conditions on the bridge as a whole. A few times loggers malfunctioned and thus only one value was available and was taken in place of the average.

We used data on air temperature (measured $2 \mathrm{~m}$ above ground) and precipitation for the sampling period obtained from the weather station at Basel/Binningen ( $4 \mathrm{~km}$ distance from the bridge). Weather data were available as minimum, mean and maximum temperatures and total precipitation per calendar day, as semi-daily totals, or per $24 \mathrm{~h}$ period lasting from 5:40 on one day to 5:40 on the next day, as well as $12 \mathrm{~h}$ periods between 5:40-17:40 and 17:40-5:40. We used the latter periods rather than data for calendar days for analyses of weather effects on invertebrate abundances in the traps, as a better fit to our day and night collections of invertebrates. Long-term data on temperature and precipitation (climate norms; average of each month from 1981 to 2010) were obtained from the same weather station and compared to monthly values computed for the study period based on the data for calendar days.

\subsection{Trait Analysis}

The special conditions in the gravel bed on the bridge may function as a filter for dispersing species. Species with particular traits might be more frequently captured. A detailed analysis of species traits can only be done with groups with (1) both a large abundance and a high species diversity, (2) a known species pool for the region and (3) trait information for all species. In our study only two groups fulfilled these criteria: ants and spiders. However, we excluded ants from the trait analysis, because they migrate predominantly by flying.

As spider traits we considered body size (without legs) for both females and males as reported in Nentwig et al. [26]. Body size is related to the ability of the species to use interstices in the gravel bed and is related to active dispersal on the ground. We further considered the vertical distribution of the species in their habitats (ordinal scale: $0=$ beneath stones, in soil, in caves or animal burrows and nests, $1=$ on soil surface or in litter layer, $2=$ in herb layer, $3=$ on bushes, lower twigs of trees, lower part of tree trunk, $4=$ on trees, higher boughs, middle part of tree trunk, $5=$ in canopy of trees; obtained from Maurer and Hänggi [27]). Spider species mainly occurring in higher strata (classes 4 and 5) would not find suitable habitat on the bridge itself and thus when found may use the bridge as a dispersal corridor.

The conditions on the bridge (gravel instead of soil, reduced vegetation layer lacking trees) may act as a filter excluding species with certain traits. To examine whether spider species caught on the bridge differ in stratum use and body size from the regional fauna we compared the distributions of these traits to an overall regional species list compiled from several studies that applied pitfall traps in the urban area of Basel (Zoo Basel [28]; urban forests [29]; urban gardens: Braschler, Gilgado, Zwahlen, Rusterholz, Buchholz and Baur, unpublished data). The combined list comprised 165 species. However, for 12 species (7.3\%) information on stratum use was not available. This included 5 species (12.8\% of 39 species), which were caught on the bridge.

\subsection{Statistical Analyses}

We decided to aggregate data for 7-day periods because in many taxonomic groups no individuals were captured on many days. Accordingly, temperature and precipitation data were compiled to the same 7-day-periods. We used Pearson correlation to examine the correlation between temperatures in the gravel bed and air temperatures from the weather station. One 7-day period had to be omitted from analyses because of missing temperature data for 2 days.

We used generalized linear models (GLM; see Supplementary Table S1 for details of the models) to examine the effects of weather conditions on the abundance in traps of different taxonomic groups. Different taxonomical groups may react to temperature in different ways. Some groups may respond to mean temperatures, while other groups may be more sensitive to temperature extremes. We used four different variables reflecting different temperature aspects. This enabled us to differentiate between these responses. The analyses had to be run separately for each of these temperature variables, as they 
were highly intercorrelated. We used the following variables matching the trap collection schedule: grand mean temperature (defined as the mean of daily mean temperatures for a timespan of 7 days, whereby the days ran from the morning emptying of the traps to the emptying of the traps $24 \mathrm{~h}$ later on the following morning), maximum mean temperature (the highest daily mean temperature from a 7-day period), mean maximum temperature (the mean of the highest measured temperatures for the 7-day period) and absolute maximum temperature (the highest temperature measured during the 7-day period), all of which were based on the half-hourly measured temperatures from the gravel bed, and precipitation (summed precipitation for the 7-day period starting at 5:40 on the first day, with data obtained from the weather station). Models were also run using corresponding variables for the morning (representing nocturnal activity) and evening (representing diurnal activity) emptying of traps only. The exception was precipitation for which no half-day data were available. For comparison with long-term climatic conditions, weather data based on calendar days was used and aggregated for 7-day periods or monthly. For monthly summaries of the data only the months April to October were used, as temperatures on the bridge were not measured from the start of March. The data from the year of the study was then compared to norm values for the months April through October weather station based data from 1981-2010.

Animals from the collections at dawn were considered to have been active during the night, while animals found in the traps at nightfall were considered to have been active during the day. To examine seasonal variations in activity, we split the study period into four periods of equal length (spring: 7 March to 5 May, early summer: 6 May to 3 July, late summer: 4 July to 1 September, autumn: 2 September to 31 October).

To examine whether spiders caught on the bridge differed in body size from the known spider species pool for Basel, we used $t$-tests on log-transformed body size data for females and males separately. We compared the potential use of different strata by the spiders caught on the bridge with that of the spiders known for Basel using Fisher's exact test. For potential strata use we considered all strata listed for a particular species, and combined them for all species to a common frequency distribution. Similarly, we also ran Fisher's exact tests for the lowest stratum scores and highest stratum scores for the species.

All statistical analyses were performed using R Statistical Software (R ver. 3.3.3) (www.r-project.org).

\section{Results}

\subsection{Weather Conditions on the Bridge}

In general, temperatures measured in the gravel bed (summarized over a 7-day period) were highly correlated with temperature measurements obtained from the official weather station in Basel (Basel/Binningen): grand mean temperatures for 7-day periods (mean values and range) in the gravel bed were $15.4^{\circ} \mathrm{C}\left(4.8-25.0^{\circ} \mathrm{C}\right)$ vs. $14.0^{\circ} \mathrm{C}\left(3.1-21.5^{\circ} \mathrm{C}\right)$ air temperature at the nearby weather station Basel/Binningen $(r=0.98, n=30, p<0.0001)$; maximum of daily mean temperature for 7 -day periods $21.2^{\circ} \mathrm{C}\left(8.6-32.2^{\circ} \mathrm{C}\right)$ vs. $17.0^{\circ} \mathrm{C}\left(4.3-23.6^{\circ} \mathrm{C}\right)(r=0.96, n=30, p<0.0001)$; means of maximum daily temperature for 7-day periods $19.8^{\circ} \mathrm{C}\left(8.2-33.3^{\circ} \mathrm{C}\right)$ vs. $19.3^{\circ} \mathrm{C}\left(7.6-28.7^{\circ} \mathrm{C}\right)(r=0.96, n=30, p<0.0001)$; absolute maximum temperature for 7 -day periods $29.1^{\circ} \mathrm{C}\left(14.2-46.1^{\circ} \mathrm{C}\right)$ vs. $23.3^{\circ} \mathrm{C}\left(9.5-31.9{ }^{\circ} \mathrm{C}\right)$ $(r=0.91, n=30, p<0.0001)$. Mean and maximum temperatures in the gravel bed were higher than temperatures measured in the weather station $2 \mathrm{~m}$ above ground (Figure 2a,b). However, this pattern was seasonal, with temperatures in the gravel bed higher for most of the study period, though with a declining difference after June and even lower than air temperatures in October (Figure 2a-c). Compared to the long-term temperature and precipitation data from the region (mean values from 1981-2010), the temperature in our investigation period was slightly below average $\left(14.3^{\circ} \mathrm{C}\right.$ vs. $15.2^{\circ} \mathrm{C}$ for April through October 1996; Figure 2). While precipitation was similar to the long-term average (543 vs. $571 \mathrm{~mm}$; Figure 2d) and relatively regularly distributed over the investigation period (Figure 3b), this was not true for all months (Figure 2d). August and October received markedly more precipitation 
than the long-term average (55.0\% and $25.6 \%$ ) and April and September markedly less $(57.3 \%$ and $47.7 \%$; Figure 2d). Temperature data in situ showed that temperatures in the gravel between the rails during the day were higher than those at the head of the bridge (Figure 3a).
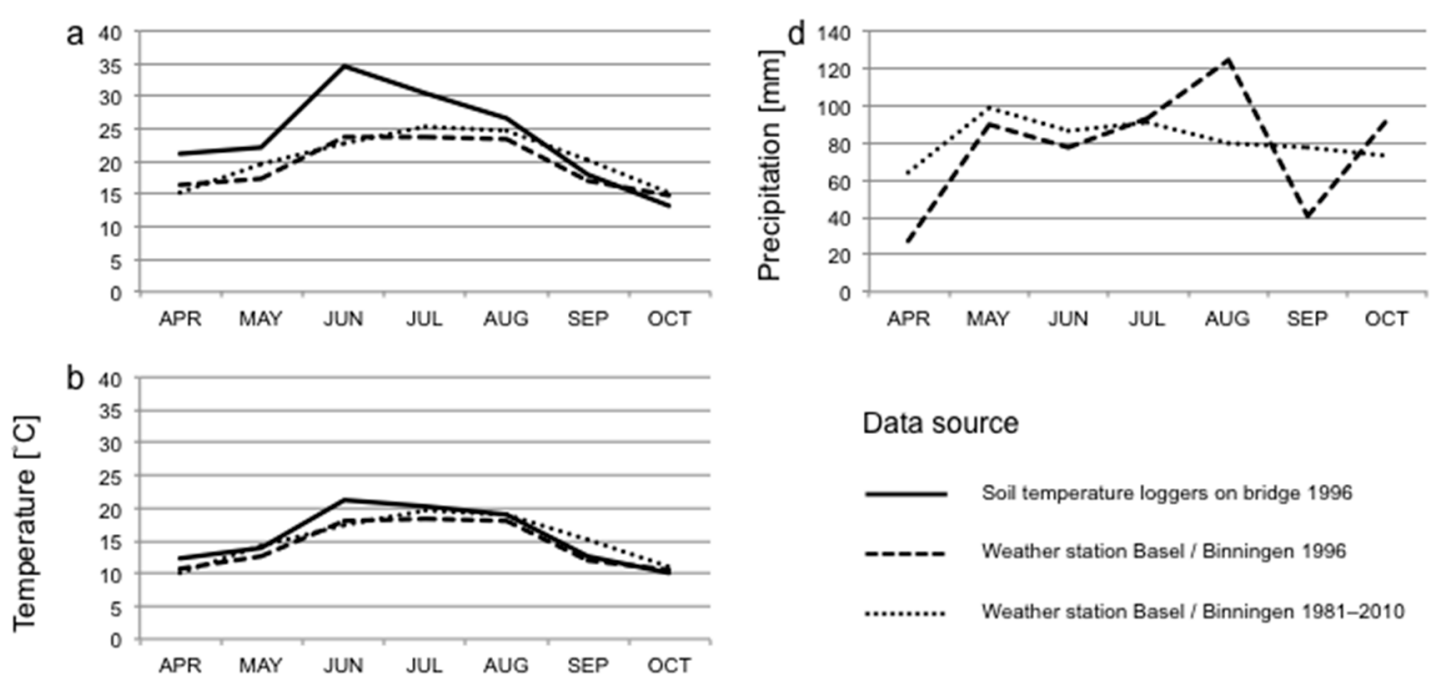

Data source
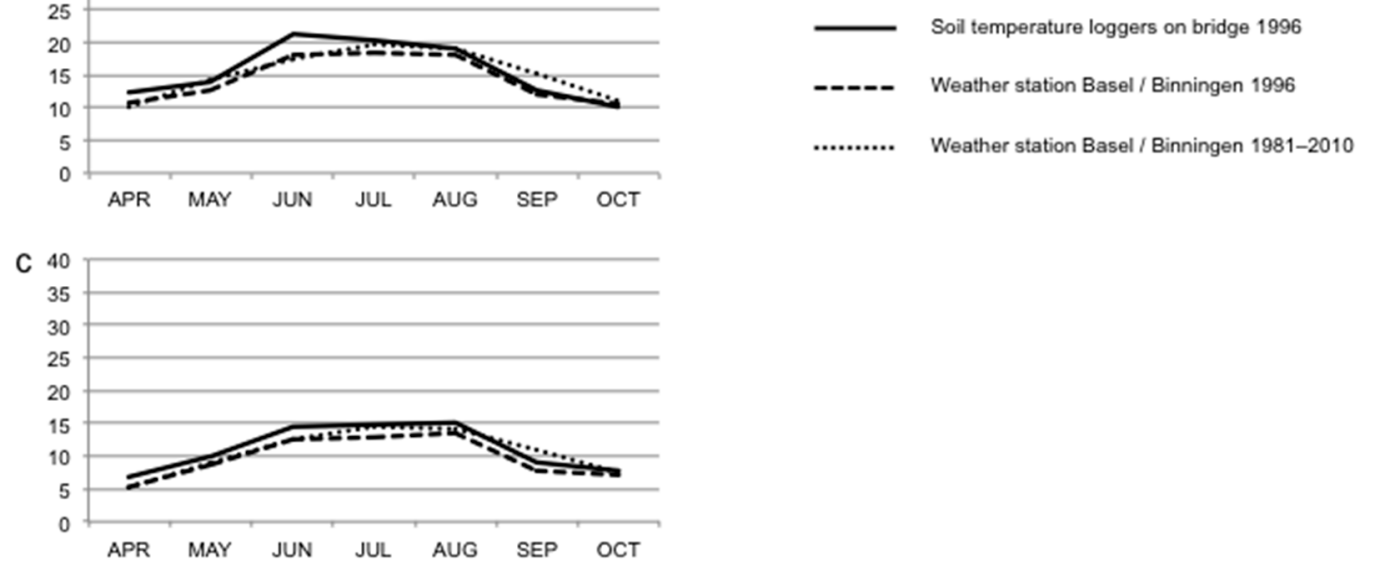

Figure 2. $(\mathbf{a}-\mathbf{c})$ Comparison of temperatures measured in the gravel bed of the bridge with air temperatures measured $2 \mathrm{~m}$ above grass at the nearby weather station Basel/Binningen. Both norm values for the period of 1981-2010 and values for the study period are given. (a) Monthly means of daily maximum temperatures, (b) monthly means of daily mean temperatures, (c) monthly means of daily minimum temperatures. (d) Comparison of summed monthly precipitation for the study period with long-term norm values (weather station Basel/Binningen).
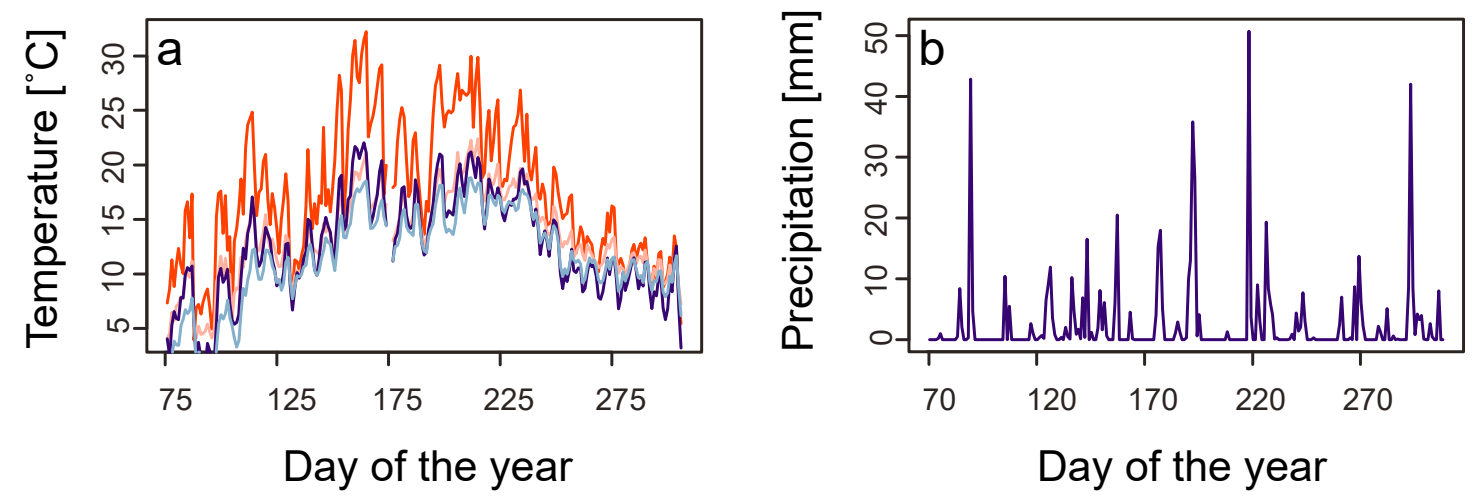

\section{Mean temperature}

Gravel bed temperature on bridge

Gravel bed temperature at head of bridge



Figure 3. (a) Mean temperatures during the day and night for the observation period for loggers in the gravel bed between the rails on the bridge and at the head of the bridge, respectively. (b) Precipitation per day at the nearby weather station Basel/Binningen. 


\subsection{Weather and Daytime Effects on Number of Animals Captured}

Considering all groups, more specimens were caught at higher temperatures (Supplementary Table S1a). Maximum mean temperature explained most of the variation in the number of individuals trapped $\left(F_{1,30}=15.79, p=0.0004\right)$. The overall abundance of individuals captured during the night was best explained by grand mean temperatures $\left(F_{1,30}=10.61, p=0.0028\right.$; Supplementary Table S1k), while the overall captures during the day were best explained by absolute maximum temperature $\left(F_{1,30}=18.84, p=0.0002\right.$; Supplementary Table S1f). Precipitation did not significantly affect combined abundance of all groups in traps (overall number of captures). These overall abundance patterns in traps were influenced by the patterns of the three most abundant groups-ants, spiders and beetles (all families combined). Abundance in traps for these groups was positively related to absolute maximum temperatures (ants: during the day (Supplementary Table S1g), during the night (Supplementary Table S1l), and overall (Supplementary Table S1b); spiders: during the day (Supplementary Table S1h) and overall (Supplementary Table S1c); beetles: overall (Supplementary Table S1d)). For spider abundance in traps at night, mean maximum temperature explained most of its variation, but was not quite significant (Supplementary Table S1m). Considering beetles (all families combined), abundance in traps was positively related to grand mean temperatures during the night (Supplementary Table S1n), but not related to temperature during the day (Supplementary Table S1i). Abundance in traps was not significantly related to precipitation for ants, spiders or beetles in the traps. The remaining groups consisted of too few individuals to be analyzed separately (Supplementary Table S2). Analyzing them together may have masked significant relationships for some groups (Supplementary Table S1e,j,o).

\subsection{Species Richness Recorded in the Traps}

We did not consider very small arthropods like mites and springtails or some groups of flying insects, such as flies, but restricted our analyses to 1168 individuals from taxonomic groups with significant soil surface activity. Taxonomic groups considered were gastropods (Gastropoda: 31 individuals, 6 species), woodlice (Isopoda: 57, 5), spiders (Aranae: 225, 39), harvestmen (Opiliones: 64, 5), millipedes (Diplopoda: 71, 4), ants (Hymenoptera: Formicidae: 491, 17 (of which 7 species were only represented by queens)), ground beetles (Coleoptera: Carabidae: 41, 16), rove beetles (Coleoptera: Staphilinidae: 15, 10), amphibians (Amphibia: 3, 2), reptiles (Reptilia: 15, 1), and small mammals (Mammalia: 8, 2). Additionally, we included 92 centipedes (Chilopoda), and 55 beetles of other families, which were captured, but not identified to species level. A detailed species list is presented in Supplementary Table S3. We also recorded footprints of foxes (Vulpes vulpes), domestic cats (Felis silvestris) and stone martens (Martes foina) in the snow cover on the bridge in February 1996, indicating that the bridge may serve as a corridor for these predators or be part of their home range. The abundance of these large mammals, which could easily cross the drift fence, was not recorded.

\subsection{Day-Night-Activity Patterns}

For analyzing day-night-activity patterns we considered data from 7 March to 31 October, because traps were emptied twice per day during this period (Figure 4). During this period 1075 individuals were captured (Figure $4 \mathrm{n}$ ). Considering all groups combined, 447 individuals were captured during the day and 628 during the night (41.6\% vs. 58.4\%, Figure 4 n). This slightly night-biased ratio holds for all seasons except spring, which had an almost equal ratio. Reptiles were exclusively caught during the day (exclusively subadult individuals of Podarcis muralis, Figure 4l). Spiders (Figure 4b), ants (Figure $4 \mathrm{~g}$ ), and rove beetles (Figure $4 \mathrm{j}$ ) were captured in similar proportion during day and night independent of season, while other groups including gastropods, harvestmen, millipedes, centipedes, woodlice and ground beetles were mostly or exclusively caught during the night (Figure $4 \mathrm{a}, \mathrm{c}-\mathrm{f}, \mathrm{i})$. In particular, amphibians (Bufo bufo and Rana temporaria) and small mammals (Apodemus sylvaticus and Crocidura russula) were exclusively caught at night (Figure $4 \mathrm{~m}, \mathrm{n}$ ). 


\subsection{Seasonal Activity Patterns}

The largest number of animals was captured in early summer, while the smallest was captured in spring (Figure 4n). Millipedes and centipedes were predominantly captured in autumn (Figure 4d,e), beetles (all families combined), harvestmen and woodlice were mostly captured in summer, especially late summer (Figure $4 \mathrm{c}, \mathrm{f}, \mathrm{h}$ ), while the largest numbers of spiders and ants were captured in early summer (Figure $4 b, g$ ).

\subsection{Use of the Bridge as Habitat or to Disperse}

Spider species captured on the bridge did not differ from the known spider species pool of the city overall with regard to body size (a trait associated with dispersal ability; log-transformed data, females: $t=1.03, n_{\text {all species }}=165, n_{\text {bridge species }}=39, p=0.31$; males: $t=1.51, n_{\text {all species }}=165, n_{\text {bridge species }}=39$, $p=0.14$ ) and vegetation stratum use (associated with habitat preferences; Fisher's exact test $p=0.80$ ). The sample from the bridge even included two arboreal species (Platnickina tincta and Salticus scenicus; strata 3-5 according to Maurer and Hänggi [27]) as well as three more species with a wide vertical niche including strata 4 or 5 . Though some young trees and bushes grew on the bridge during the year it was blocked to traffic, there was no stratum 4 or 5 habitat available. It seems likely that such arboreal species caught on the bridge were dispersers. However, the structure of the bridge itself may have provided habitat similar to that of higher branches for some species. Of the two arboreal species captured, one was a jumping spider with no web, while the other is a tangle web spider, indicating different structural requirements from their habitat
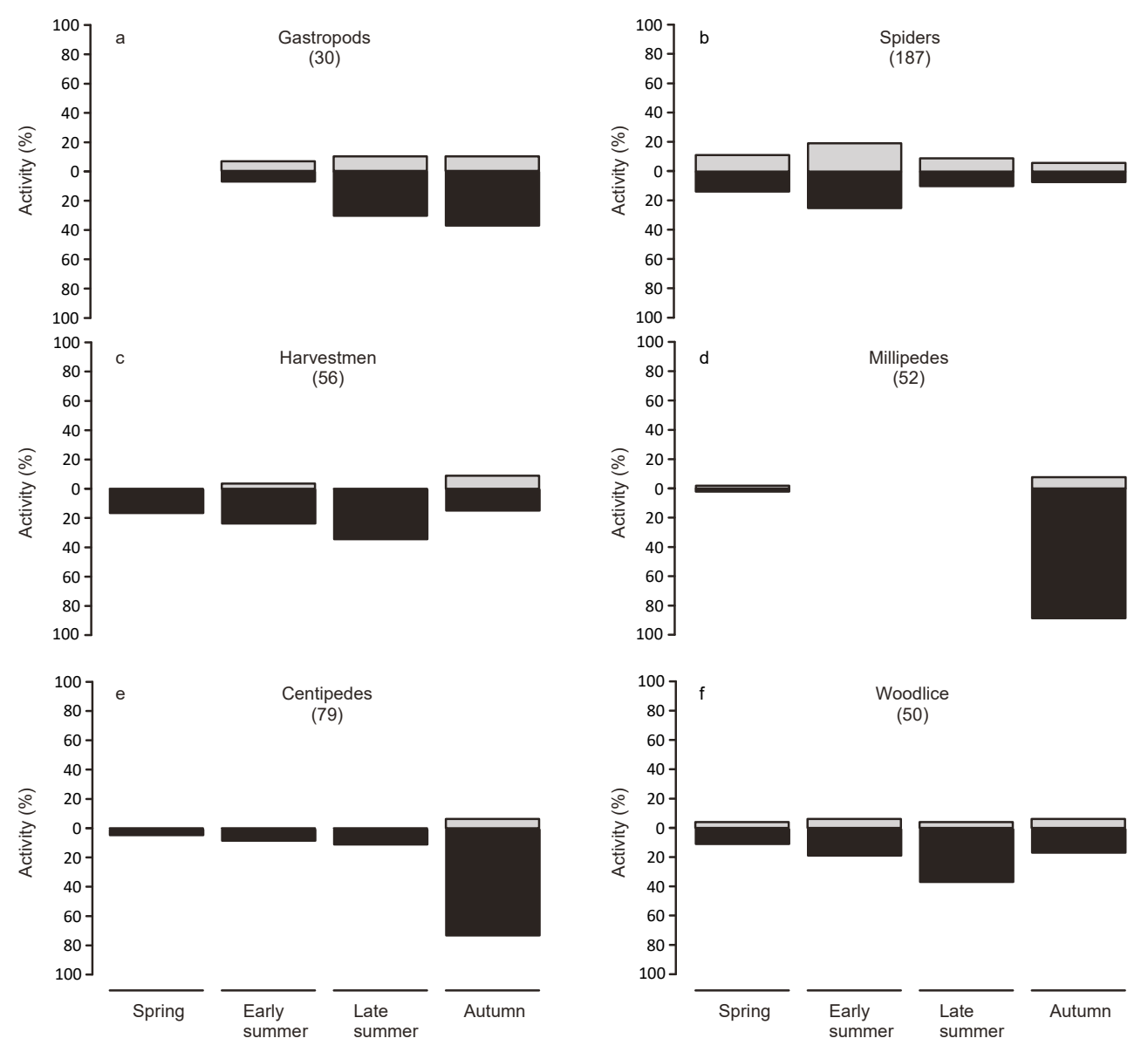

Figure 4. Cont. 

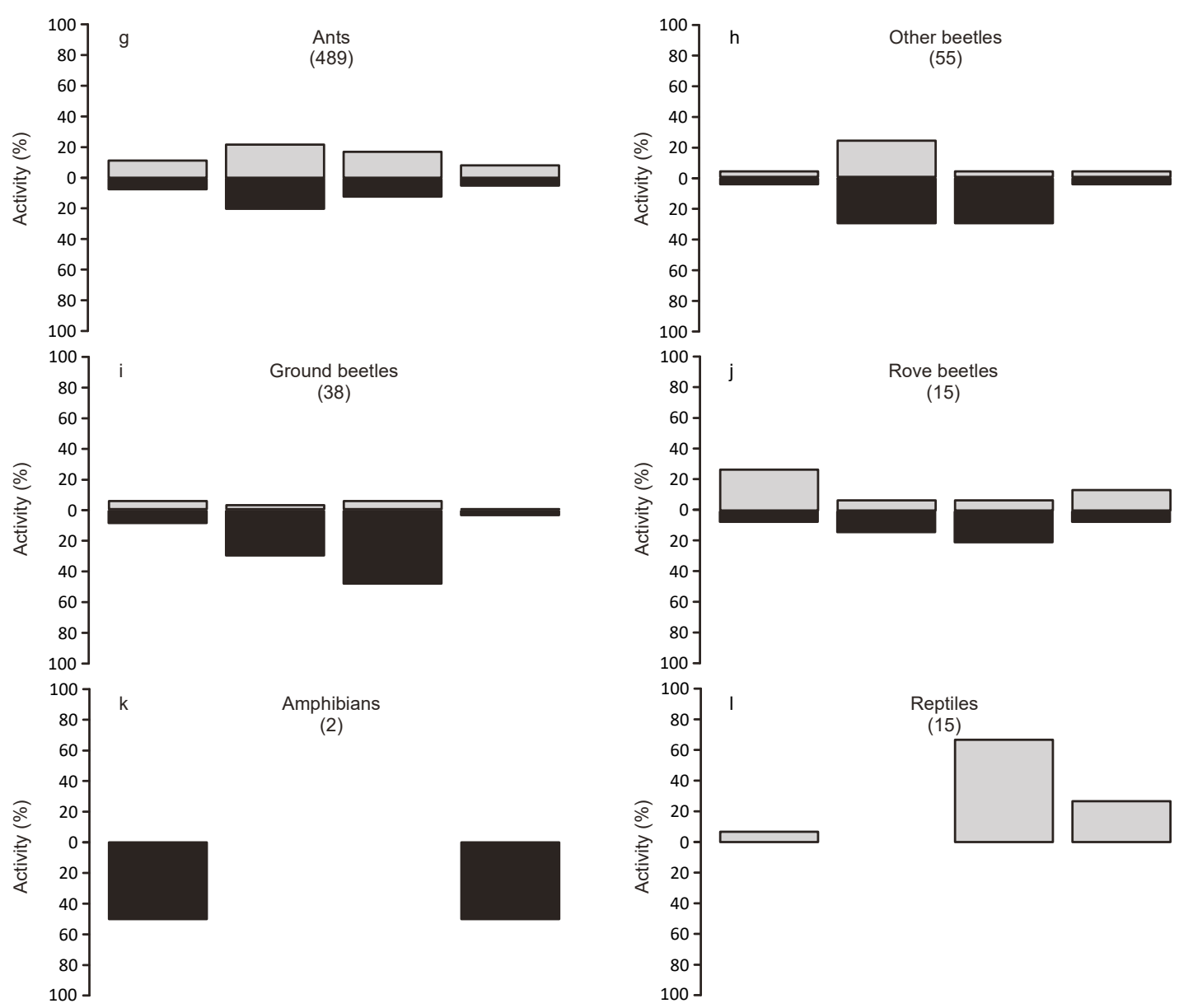

(38)

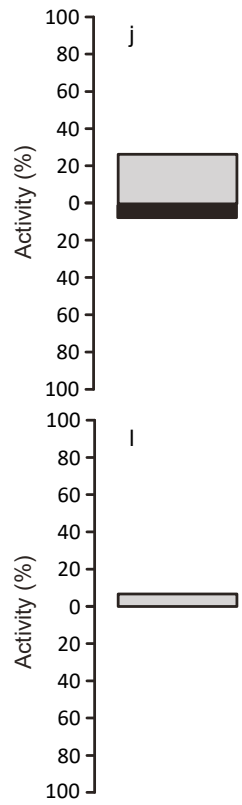

(15)


Figure 4. Activity patterns of different focal groups. (a-n) show the percentage of all individuals of a focal group caught in each of the four seasons during the day and night. Light gray bars represent daytime activity, while black bars represent activity during the night. Numbers in brackets represent the total numbers of individuals caught for each focal group. Data from November were excluded from this graph because traps were only emptied once per day in that month.

Similar to arboreal species, some specialist species for different habitat types (e.g., forest) likely used the bridge as a dispersal corridor. Other inhabitants of the railway gravel bed are also known from gravel-rich habitats such as scree fields. For these species the gravel bed on the bridge is part of the habitat provided by the greenway. Similarly, the presence of juveniles or worker ants indicates that some invertebrate species are living on the bridge. The bridge investigated in our study thus functioned both as dispersal corridor and connecting habitat. However, the two functions could not be disentangled for all invertebrate species. The case was clearer for small vertebrates. There 
were no permanent lizard populations located close to either end of the bridge, indicating that all lizards captured were migrating. Similarly, amphibians were captured on the way to their breeding or overwintering sites. Small mammals captured on the bridge were also dispersing individuals.

\section{Discussion}

\subsection{Greenways and Functional Connectivity}

The value of line-side vegetation along railway corridors for citizens and biodiversity is well established $[2,5,14]$. Though not normally accessible to citizens due to safety concerns, line-side vegetation enhances the attractiveness of the neighborhoods. Local residents feel passionately about the vegetation next to their gardens and the biodiversity harbored in those habitats [2]. Line-side vegetation also provides services such as a barrier to dust and noise by the passing trains [2]. The additional value of this habitat as a major natural asset that is important for nature conservation has been recognized in legislation and official documents $[2,14,30]$. Because of their linear shape, these greenways enhance connectivity for biodiversity within the city $[2,5,14]$. However, the potential contribution of the gravel bed of the railways to these functions has received far less attention than that of the line-side vegetation. As the gravel bed continues, even where tunnels or overpasses interrupt embankments, railway bridges may serve as important elements in greenways.

Our case study showed that even a seemingly artificial habitat, a relatively thin and uniform gravel layer on a steel construction, is a valuable asset as an element of urban greenways. Besides providing multiple ecosystem services to residents, greenways have an important function as corridors for biodiversity in urban areas. However, their functional connectivity is frequently interrupted when crossing roads and rivers, an aspect that has so far not been investigated for animals. Our case study indicates that the bridge investigated fulfilled the connectivity function for a part of the urban fauna. This included some small vertebrate species as well as species not associated with open spaces and gravel-rich habitats such as arboreal spiders, which may have arrived on the bridge by chance. Indeed, all the small mammal and reptile species recorded on the bridge were previously considered as focal species for ecological network planning [31,32]. In addition, the gravel bed on the bridge provided habitat for many resident invertebrate species, highlighting its value as part of a greenway for invertebrates. These findings are somewhat surprising with respect to the rather extreme temperatures measured in the gravel bed with maximum temperatures exceeding the air temperatures by 10 and more ${ }^{\circ} \mathrm{C}$. For animals adapted to open gravel areas this may not be a problem. However, for other animals it may reduce their likelihood of dispersal.

Tikka et al. [23] demonstrated the importance of road and railway verges as dispersal corridors for plants. Penone et al. [5] found that railway edges function as corridors for common grassland plants even in urban environments. Considering embankment gaps, functional connectivity was mainly maintained at railway stations, but not at overpasses. Plant groups differed in response depending on traits related to dispersal [5]. Similar information is scarce for animals, especially invertebrates. Morón et al. [24] showed that railway embankments can serve as a new habitat for pollinating insects (bees, butterflies, hoverflies). Similarly, Gonseth [33] reported a species-rich butterfly community on railway embankments. However, both studies did not consider the gaps in the embankments at bridges.

\subsection{Special Conditions in the Gravel Bed}

In contrast to railway embankments, the gravel bed is a more artificial habitat exposed to extreme environmental conditions. Gravel beds in general have no vegetation, which would dampen extreme temperature fluctuation. Indeed, temperature conditions in the gravel bed differed considerably from standard measurements from the nearby weather station. Mean and maximum temperatures in the gravel bed were higher than corresponding temperatures measured in the weather station.

To our knowledge, species composition of invertebrates has not been investigated in gravel beds. However, large gravel areas such as in marshaling yards serve as habitats for many xerothermophilic 
and pioneer species [34,35]. Furthermore, some of the railway habitats show a high overlap with species composition of ruderal sites in urban areas [14,36]. Interestingly, $65 \%$ of the carabid and staphilinid beetle species captured on the bridge were also recorded in natural gravel beds along the river Rhine in the Upper Rhine Valley [37]. Similar data for other groups are lacking. Railway gravel beds may function as connecting habitat corridors for species occurring in natural or semi-natural gravel-rich habitats and ruderal sites in the urban area.

\subsection{Daily and Seasonal Activity Patterns}

Twice daily collection allowed us to discern diurnal and nocturnal activity patterns. Our results indicate that the majority of the surface activity happened during the night. However, this differed strongly depending on the taxonomic group. Extreme temperatures during the day may act as a filter for the use as habitat by some groups, which, however, may still disperse on the bridge during more benign conditions. However, many species may be mostly nocturnal independent of the weather conditions. Indeed most of the groups represented in the traps were predominately caught during the night.

These findings are relevant for future management of little-used railway lines in urban areas, particularly for industrial railway lines used for occasional cargo transport. If these cargo transports were restricted to the daytime this would increase the functional connectivity of these railway lines during the night.

\subsection{Traits}

To understand the function of the railway bridge as part of the greenway, it is necessary to understand whether species using the bridge are representative for the wider species pool of the region or represent a subset of this pool characterized by certain traits or habitat preferences. In our case study, spider species captured on the bridge did not differ in body size and stratum use from the overall species pool of the urban area of Basel. A body size distribution in line with that of the species pool indicates that the bridge is suitable for dispersal for spiders of all sizes. Furthermore, the scale of interstices in the gravel bed may not limit use for spiders because of a reduced amount of fine-grained substrate. In contrast to our expectation, we also found arboreal species on the bridge. Like other invertebrate species, which are typically found in habitats very dissimilar to the open and exposed gravel bed on the bridge, these species were likely dispersing. However, as numbers for these species were low they may also have arrived on the bridge by chance. This highlights the function of the bridge as an important element of a corridor network of linear structures connecting green spaces throughout the urban area.

\subsection{Conclusions}

Beside a proven dispersal function for vertebrates, we provided evidence for a species-rich invertebrate community in the gravel bed on this set-aside iron-steel railway bridge. It should be noted that in the decade prior to our investigation period the railway bridge was primarily used for irregular goods transports rather than regular passenger traffic. In this respect the railway line investigated may resemble many industrial railway lines. By contrast, information on invertebrate communities in the gravel bed of heavily used tracks is not known. Planned traffic blockages for rail maintenance may allow studying some aspects of gravel-inhabiting invertebrate communities. Newly abandoned railway lines may also provide research opportunities.

Why is the case of our bridge relevant beyond Basel? First, we show the reuse value of set-aside transportation infrastructure for biodiversity. This is of particular importance because of limited budgets for urban greenways. This approach may appeal to transportation managers and politicians alike because of its potential reversibility, allowing flexibility in face of changing demands. Currently, the railway bridge investigated in Basel is still set aside, functioning as a dispersal corridor. Second, the fact that most animals were captured during the night opens an opportunity for biodiversity 
management of little-used cargo tracks. If industrial railway tracks are exclusively used during the day, individuals of many taxonomic groups would be able to disperse during the night. Such changes in usage may be more easily and faster achievable than the augmentation of existing infrastructure or the construction of new green bridges, and may improve connectivity of urban habitats. Thus, even minor management changes could enhance the connectivity function of greenways.

Supplementary Materials: The following are available online at http://www.mdpi.com/2071-1050/12/3/1194/s1, Table S1: Summaries of generalized linear models (GLM) examining the effects of temperature and precipitation on the abundance of invertebrates caught; Table S2: Capture data for different animal groups per 7-day period; Table S3: List of invertebrate species captured.

Author Contributions: Conceptualization, B.B. (Bruno Baur); Formal analysis, B.B. (Brigitte Braschler); Funding acquisition, B.B. (Bruno Baur); Investigation, C.D.; Project administration, C.D.; Visualization, B.B. (Brigitte Braschler); Writing —original draft, B.B. (Brigitte Braschler) and B.B. (Bruno Baur); Writing-review and editing, B.B. (Brigitte Braschler) and B.B. (Bruno Baur). All authors have read and agreed to the published version of the manuscript.

Funding: Financial support was received from the Emilia Guggenheim-Schnurr Stiftung, Basel, Grant No. 96-07.

Acknowledgments: We are grateful to the Deutsche Bahn AG for permission to conduct the study on the set-aside bridge. C. Berney, M. Wurtz and several students are thanked for help with fieldwork. We thank the following experts for help with species identifications: C. Berney, A. Coray, A. Hänggi, H. Luka, T. Meier, R. Neumayer, A. Pedroli-Christen, P. Stucki, P. Vogel, I. G. Weiss, A. Wittwer and D. Wyniger. We thank S. Friry for assisting with retrieving trait data for spider species. H.-P. Rusterholz, J.D. Gilgado, I. Kowarik and three anonymous reviewers are thanked for comments on the manuscript.

Conflicts of Interest: The authors declare no conflict of interest. The funders had no role in the design of the study; in the collection, analyses, or interpretation of data; in the writing of the manuscript, or in the decision to publish the results.

\section{References}

1. Grimm, N.B.; Faeth, S.H.; Golubiewski, N.E.; Redman, C.L.; Wu, J.; Bai, X.; Briggs, J.M. Global change and the ecology of cities. Science 2008, 319, 756-760. [CrossRef]

2. London Assembly: Environment Committee. On the Right Lines? Vegetation Management on London's Railway Embankments; Greater London Authority: London, UK, 2012.

3. Liang, H.; Chen, D.; Zhang, Q. Assessing urban green space distribution in a compact megacity by landscape metrics. J. Environ. Eng. Landsc. Manag. 2017, 25, 64-74. [CrossRef]

4. The World Health Organisation Regional Office for Europe. Urban Green Spaces: A Brief for Action. 2017. Available online: http://www.euro.who.int/en/health-topics/environment-and-health/urban-health/ publications/2017/urban-green-spaces-a-brief-for-action-2017 (accessed on 6 January 2020).

5. Penone, C.; Macon, N.; Julliard, R.; Le Viol, I. Do railway edges provide functional connectivity for plant communities in an urban context? Biol. Conserv. 2012, 148, 126-133. [CrossRef]

6. Kowarik, I. The "Green Belt Berlin": Establishing a greenway where the Berlin Wall once stood by integrating ecological, social and cultural approaches. Landsc. Urban Plan. 2019, 184, 12-22. [CrossRef]

7. von Haaren, C.; Reich, M. The German way to greenways and habitat networks. Landsc. Urban Plan. 2006, 76, 7-22. [CrossRef]

8. Ignatieva, M.; Stewart, G.H.; Meurk, C. Planning and design of ecological networks in urban areas. Landsc. Ecol. Eng. 2011, 7, 17-25. [CrossRef]

9. Shafer, C.S.; Scott, D.; Mixon, J. A greenway classification system: Defining the function and character of greenways in urban areas. J. Park Recreat. Admin. 2000, 18, 88-106.

10. Güneralp, B.; Seto, K.C. Futures of global urban expansion: Uncertainties and implications for biodiversity conservation. Environ. Res. Lett. 2013, 8, 014025. [CrossRef]

11. Haaland, C.; Konijnendijk van den Bosch, C.C. Challenges and strategies for urban green-space planning in cities undergoing densification: A review. Urban Forest. Urban Green. 2015, 14, 760-771. [CrossRef]

12. Jim, C.Y.; Chen, S.S. Comprehensive greenspace planning based on landscape ecology principles in compact Nanjing city, China. Landsc. Urban Plan. 2003, 65, 95-116. [CrossRef]

13. Koijnendijk, C.C. The Forest and the City: The Cultural Landscape of Urban Woodland, 2nd ed.; Springer: Cham, Switzerland, 2008. 
14. Reisner, Y.; Plattner, M.; Berney, C.; Birrer, S.; Farrèr, C.; Frei, M.; Küry, D.; Ramseier, P.; Steck, C.; Zemp, M. Unbekannte Schätze vor der Haustür - Ergebnisse des Naturinventars im Kanton Basel-Stadt; Bau- und Verkehrsdepartement des Kanton Basel-Stadt, Stadtgärtnerei: Basel, Switzerland, 2013.

15. London Biodiversity Partnership. The London Biodiversity Audit. Volume 1 of the London Biodiversity Action Plan. 2000. Available online: https://lbp.org.uk/auditintro2.htm (accessed on 30 September 2019).

16. Baur, A.; Baur, B. Are roads barriers to dispersal in the land snail Arianta arbustorum? Can. J. Zool. 1990, 68, 613-617. [CrossRef]

17. Saunders, D.A.; Hobbs, R.J. The Role of Corridors. Nature Conservation 2; Surrey Beatty \& Sons PTY Limited: Chipping Norton, Australia, 1991.

18. Forman, R.T.T. Land Mosaics: The Ecology of Landscapes and Regions; Cambridge University Press: Cambridge, UK, 1995.

19. Canters, K.; Piepers, A.; Hendriks-Heersma, D. (Eds.) Habitat Fragmentation and Infrastructure; Ministery of Transport, Public Works and Water Management: Delft, The Netherlands, 1997.

20. Clevenger, A.P. Conservation value of wildlife crossings: Measures of performance and directions. Gaia 2005, 14, 124-129. [CrossRef]

21. van der Grift, E.A. Defragmentation in the Netherlands: A success story? Gaia 2005, 14, 144-147. [CrossRef]

22. Brodtbeck, T.; Zemp, M.; Frei, M.; Kienzle, U.; Knecht, D. Flora von Basel und Umgebung 1980-1996. Teil 1. Mitt. Naturforsch. Ges. beider Basel 1997, 2, 1-543.

23. Tikka, P.M.; Högmander, H.; Koski, P.S. Road and railway verges serve as dispersal corridors for grassland plants. Landsc Ecol. 2001, 16, 659-666. [CrossRef]

24. Morón, D.; Skórka, P.; Lenda, M.; Rożej-Pabijan, E.; Wantuch, M.; Kajzer-Bonk, J.; Celary, W.; Mielczarek, Ł.E.; Tryjanowski, P. Railway embankments as new habitat for pollinators in an agricultural landscape. PLoS ONE 2014, 9, e101297. [CrossRef] [PubMed]

25. Bennett, A.F. Linkages in the Landscape: The Role of Corridors and Connectivity in Wildlife Conservation (No. 1); IUCN: Gland, Switzerland; Cambridge, UK, 2003.

26. Nentwig, W.; Blick, T.; Gloor, D.; Hänggi, A.; Kropf, C. (Eds.) Araneae: Spiders of Europe. Available online: https://araneae.nmbe.ch (accessed on 23 September 2019).

27. Maurer, R.; Hänggi, A. Katalog der schweizerischen Spinnen/Catalogue des araignées de Suisse; Documenta Faunistica Helvetiae 12; Schweizerischer Bund für Naturschutz \& Centre Suisse de cartographie de la faune (CSCF)/Schweizerisches Zentrum für die kartographische Erfassung der Fauna (SZKF): Neuchâtel, Switzerland, 1990.

28. Gloor, D.; Hänggi, A.; Bolzern, A. Spinnentiere. In Vielfalt zwischen den Gehegen: Wildlebende Tiere und Pflanzen im Zoo Basel. Monographien der Entomologischen Gesellschaft Basel, Volume 3; Baur, B., Billen, W., Burckhardt, D., Eds.; Entomologische Gesellschaft Basel: Basel, Switzerland, 2008; pp. 213-232.

29. Melliger, R.L.; Braschler, B.; Rusterholz, H.-P.; Baur, B. Diverse effects of degree of urbanization and forest size on species richness and functional diversity of plants, and ground surface-active ants and spiders. PLoS ONE 2018, 13, e0199245. [CrossRef]

30. Zhao, X.G.; Pan, Y. Greenway: Origin, planning features and significance. Appl. Mech. Mat. 2013, 295-298, 2660-2664. [CrossRef]

31. Battisti, C.; Luiselli, L. Selecting focal species in ecological network planning following an expert-based approach: Italian reptiles as a case study. J. Nat. Conserv. 2011, 19, 126-130. [CrossRef]

32. Spinozzi, F.; Battisti, C.; Bologna, M.A. Habitat fragmentation sensitivity in mammals: A target selection for landscape planning comparing two different approaches (bibliographic review and expert based). Rend. Lincei 2012, 23, 365-373. [CrossRef]

33. Gonseth, Y. La faune des Lépidoptères diurnes (Rhopalocera) des talus routiers et ferroviaires du Jura neuchâtelois. Mitt. Schw. Entomol. Ges. 1992, 65, 413-430.

34. Bönsel, D.; Malten, A.; Wagner, S.; Zizka, G. Flora, Fauna und Biotoptypen von Haupt- und Güterbahnhof in Frankfurt am Main, Kleine Senkenberg-Reihe 38; Waldemar Kramer GmbH: Frankfurt a. M., Germany, 2000.

35. Burckhardt, D.; Baur, B.; Studer, A. (Eds.) Fauna und Flora auf dem Eisenbahngelände im Norden Basels. Monographien der Entomologischen Gesellschaft Basel, Volume 1; Entomologische Gesellschaft Basel: Basel, Switzerland, 2003. 
36. Melliger, R.L.; Rusterholz, H.-P.; Baur, B. Habitat- and matrix-related differences in species diversity and trait richness of vascular plants, Orthoptera and Lepidoptera in an urban landscape. Urban Ecosyst. 2017, 20 , 1095-1107. [CrossRef]

37. Bense, U.; Maus, C.; Mauser, J.; Neumann, C.; Trautner, J. Die Käfer der Markgräfler Trockenaue. In Vom Wildstrom zur Trockenaue: Natur und Geschichte der Flusslandschaft am südlichen Oberrhein; Landesanstalt für Umweltschutz Baden-Württemberg (LfU), Ed.; Verlag Regionalkultur: Ubstadt-Weiher, Germany, 2000.

(C) 2020 by the authors. Licensee MDPI, Basel, Switzerland. This article is an open access article distributed under the terms and conditions of the Creative Commons Attribution (CC BY) license (http://creativecommons.org/licenses/by/4.0/). 